\title{
Reframing and Reconceptualising Gambling tourism in Macau as a Chinese Pilgrimage
}

\author{
Michael O'Regan ${ }^{\mathrm{a}}, \mathrm{PhD}$ (Primary Author), Senior Lecturer, Jaeyeon Choe, \\ PhD Senior Lecturer and Michael Di Giovine ${ }^{b}, \mathrm{PhD}$, Associate Professor of \\ Anthropology \\ ${ }^{a}$ Bournemouth University; ${ }^{b}$ West Chester University of Pennsylvania
}

\begin{abstract}
While dominant discourses, media representations and corporate entities in China downplay the presence of Chinese mainland gambling in Macau, Beijing sanctions millions of its citizens to make the journey to Macau to gamble each year. While Macau's success is often put down to the extent to which visitors are drawn to a secular destination with integrated resorts to engage in individualistic activities, our approach explores Chinese gambling tourists' movements, rituals and behaviours along poststructuralist lines, so as to generate new insights. The analysis shows how the metaphor of pilgrimage is an important lens to address individual and communal practices amongst outbound Chinese gambling tourists and brings to light the hyper-meaningfulness, shared values, ritualization, play, risk, and liminal conditions that characterise the processes of their entanglements and the centrality of commercial and political interests. In particular, the analysis indicates the need to explore the significance of cultural, spiritual, economic and social dimensions of Chinese outbound tourism, as well as the unique discourses of power and control affecting their movement and practices. By reframing and reconceptualising gambling tourists as a Chinese pilgrimage, we account for manifestations of culture, governmentality and intentional ritualization as well as contribute an alternative construction of pilgrimage beyond euro-centric accounts, which in turn, will stimulate discussion on geographies of pilgrimage.
\end{abstract}

\section{摘要}

尽管在中国占主导地位的言论、媒体报道和企业实体淡化了中国 内地博彩业在澳门的存在，但中国政府对每年数以百万计的中国 公民前往澳门赌博的行为进行了制裁。虽然澳门的成功常常被归 结为吸引游客来一个有综合度假区的世俗的旅游目的地，参与个 人化的活动，但我们的路径是在后结构主义脉络下探索了中国赌 博游客的运动，仪式及行为，以获得新的见解。分析显示了朝圣的 隐喻是一种重要的透镜, 来解决中国出境赌博游客的个人和公共 实践问题，揭示了超意义化、共享价值观，仪式化，游戏、风险和 阈限条件,描述他们赌博实践的复杂过程以及商业和政治利盆的一 致性。特别的是，分析表明了中国出境游文化、精神、经济和社 会层面的重要性，以及对影响他们行动和实践的权力和控制的独 特论述。通过将赌博游客重新定义为中国人的朝圣之旅，我们解

\section{ARTICLE HISTORY}

Received 14 June 2017

Accepted 21 October 2018

\section{KEYWORDS}

Tourism; Pilgrimage; China; Macau; Rituals; Post-

structuralist methodology;

Ritualization

关键词

旅游; 朝圣; 中国; 澳门 ；仪式；后结构主义方法 论; 仪式化 
释了文化、政府管制和刻意仪式化的表现，并提供了超越以欧洲 为中心的论述另一种视角建构朝圣之旅，进而也将促进对朝圣地 理学的讨论。

\section{Introduction}

Macau is located at the mouth of the Pearl River Delta, west of Hong Kong, and bordered to the north by Guangdong province. Even after it passed to Chinese control in 1999, Macau remains a space routinely described as an east-west portal, a bridgehead, gateway, stepping stone, frontier, door way, disputed territory, crossroads, nation-nonstate and even 'drifting island' (Cheng, 1999). Under the 'one country, two systems,' model established by the 1987 Sino-Portuguese Joint Declaration, Macau Special Administrative Region [MSAR] of the People's Republic of China became the only place in greater China where table gambling is legal. Its 35 casinos produced gross gaming revenues of US\$33bn in 2017 (up from US\$1.6bn in 1999) and attracted 32.6 million visitors (800,000 in 1999). The vast increases are largely down to how Beijing controls visas, with mainland visitors only allowed to travel to Macau by way of business visas, group tours, transit visas and the individual visit scheme (IVS). The IVS allows residents of mainland cities (currently set at 49) to apply for a visa in an individual capacity. Mainland visitors made up 29 million of the total number of visitors in 2017, with 48 per cent arriving through the IVS. A 2011 University of Macau (UM) - Macau Visitor Profile Study found that $47 \%$ of visitors (out of 7,314 interviews) either 'had gambled' or 'planned to gamble' in local casinos during their visit, while a survey of 1,204 mainland visitors in 2012 found that $47.2 \%$ of mainland visitors had gambled (Zeng, Prentice, \& King, 2012). However, official discourses seek to position Macau as the 'World Centre of Tourism and Leisure', with the 2017 master plan not mentioning gambling tourists (MGTO, 2017). The positioning of gamblers to Macau in scholarly work has boxed the gambling phenomenon in Macau into Eurocentric structural-functionalist and positivistic accounts of leisure and rationality.

The purpose of this study is to move beyond what is already 'known' by exploring the realities of Chinese gamblers in Macau through their stories, words and actions. Chinese visitors to Macau are not a free floating population, given they reflect the society, history and culture in which they come from, as well as the administrative controls on their movement. Whilst researchers are prone to apply a priori reasoning on the growth of outbound Chinese tourism, a post-structuralist methodology seeks to explore areas such as meanings, practices, relationalities, spatialities, subjectivities, power and control. It is a methodology that does not look to identify themes in participant responses, but instead, identify meanings in stories that are context specific. 'Going against the grain' of established canons, facts, categories, distinctions, and boundaries, the study explores informants as part of a larger group whose identities are historically constituted. Rather than see a seemingly rational Chinese tourist culture, the authors came to understand Chinese gambler stories and activities involving movement, hyper-meaningfulness, ritualization, shared values, play, and risk as a pilgrimage. Our use of pilgrimage as a metaphor is not descriptive gloss, but a notion 
that is directly applicable to gamblers to Macau. By isolating shared meanings, spatialities and practices, the study contributes to our outstanding of intersections between tourism and pilgrimage, Chinese pilgrimage characteristics, such as liminal space, sacred places and temple festivals and how such findings diverge from extant research on western pilgrimage. The study also contributes to our understanding of power, control and release within the pilgrimage to Macau.

\section{Literature Review}

The study framework is based on a literature review that finds pilgrimage is a fluid metaphor within western (research) contexts. While Morinis (1992, p. 4) broadly describes it as 'a journey undertaken by a person in quest of a place or a state that he or she believes to embody a valued ideal', Turner and Turner (1978) introduced several fundamental linkages between pilgrimage and tourism. Importantly, they note how a tourist is half a pilgrim, if a pilgrim is half a tourist' (p. 20), with many individuals motivated to pilgrimage for recreation or entertainment. Likewise, tourism can be seen as a secular substitute for organized religion as it provides tourists with the opportunity to seek meaning through the rituals of sightseeing (Timothy \& Olsen, 2006). Eade (1992) argues that unitary categories such as pilgrim and tourist are superficial, whilst Santos (2002) argues there is hardly any difference between them. More recently, authors see a merging of the sacred and secular qualities of pilgrimage and tourism (Raj \& Griffin, 2015) with tourists metaphorically compared to pilgrims as 'a kind of conceptual shorthand' (Moore, 2004, p.73). Through 'a wide range of approaches academic, confessional, personal and canonical' (Coleman \& Elsner, 1995, p. 8), pilgrimages has been linked to the religious sphere (Maddrell \& della Dora, 2013), the cultural sphere (e.g. Elvis's Graceland), nationalism (e.g. monuments, graves, battlefields) and personal motivations (visiting or returning to an important place) (Olsen, 2016). Pilgrimage is increasingly tied up with touristic characteristics of transience, spectatorship, non-engagement with the local culture and moral irresponsibility (Tidball, 2004) with Ron (2009, p. 290) describing pilgrimage as simply 'a sub-type, or form, of tourism'. Collins-Kreiner (2016) argues, for example, that 'Pilgrimage Tourism' can be explored using the 'product lifecycle' (PLC) model. Pilgrimage has more recently caught the attention of geographers (Dwyer, 2016; Scriven, 2014), who have largely explored the concept of pilgrimage around Western examples of 'secular' or 'postsecular' pilgrimage (Dubisch \& Winkelman, 2005; Hede \& Hall, 2012; Herrero \& Roseman, 2015; Di Giovine \& Picard, 2015). While the pilgrimage metaphor is a phenomenon in constant change, China is often represented as a post-secular society, with scholarship largely focused on historical pilgrimages (Naquin \& Yu, 1992) rather than any exploration of any current manifestations of pilgrimage.

\section{Methodology}

The global spread of gambling has been critically explored with various overlapping definitions which acknowledge, identify and demarcate gamblers as distinct socio-cultural formations. Conventional studies, however, often strip the experience of 
Table 1. Informant information. Source: Authors.

\begin{tabular}{lllll}
\hline Interviewees & & & & \\
\hline & Gender, Age & Ethnicity & \multicolumn{1}{c}{ Education } & Occupation \\
\hline Sam & Male, 28 & Chinese & Secondary School & Business man \\
John & Male,46 & Chinese & Primary School & Construction worker \\
Mary & Female, 62 & Chinese & Postgraduate & Retired \\
Peter & Male, 22 & Chinese & Graduate & Student \\
Fred & Male, 35 & Chinese & Graduate & Salesman \\
Jackie & Female, 52 & Chinese & Higher Diploma & Fashion Designer \\
Jane & Female, 42 & Chinese & Graduate & Unknown \\
Jenny & Female, 55 55 & Chinese & Vocational education & Retired \\
Nick & Male, 47 & Chinese & Vocational education & Self-employed \\
Martin & Male, 25 & Chinese & Graduate & Employed \\
Matt & Male, 24 & Chinese & Graduate & Bank Official \\
Pat & Male, 28 & Chinese & Graduate & Employed \\
\hline
\end{tabular}

gambling tourism of its creativity, colour, character and context. The authors hired two Mandarin speaking assistants to interview mainland gamblers to Macau about their journey and experiences during the fall of 2014 and the summer of 2015. Twelve informants, using purposeful sampling, were interviewed in Mandarin in various public locations around casinos for between 30 and 45 minutes (see Table 1). The aim was to extract stories, so as to understand Chinese gamblers who visit Macau. Storylines are naturalized and conventional cultural narratives that can be used as the explanatory framework of one's own and others' practices and sequences of action (Søndergaard, 2002). Saturated with shared cultural meanings, given the particular discursive situation, the stories were accepted as representative of Chinese gamblers in Macau. In a process called 'translation - back translation,' the interview data was translated and transcribed into English, and then translated into simplified Chinese to ensure accuracy. The study uses post-structuralist notions of the subject to create a multifaceted interpretation of the informant's speech and actions. Rather than treat their stories as clear linear narratives that could be analysed into themes through thematic analysis, the authors consider informants dynamic entities, produced in a geographic, social, historical and political context and within a specific discursive formation (Hall, 1997). As identities are constructed within, not outside discourse, poststructuralist thinking explores how truth is unavoidably constructed, with comprehension emerging from incomplete, subjective positions. The post-structuralist approach didn't prioritise a single epistemology or Eurocentric systems of knowledge production such as thematic analysis (Braun \& Clarke, 2006).

As poststructuralist-inspired empirical analysis is not something that can be acquired as a sort of technique, scholars have struggled with the role of interviews in the conduct of research (St Pierre \& Jackson, 2014). While the primary authors had spent two years as Macau based academics, our foreign background made us outsiders. While our Mandarin speaking assistants provided access to informants, the authors utilised their position to draw out gambling stories that local researchers rarely do, as there can be professional consequences of turning one's gaze into the gambling industry in Macau (cf. Chen, 2017, pp. 164-165). The aim was to seek a standard of internal coherence or analysis which 'hangs together' and is 'non-selfcontradictory' (Madill, Jordan, \& Shirley. 2000). The authors had access to interview 
data, various forms of practices and performances and as well the social, cultural and material environment in which informants were subject. This study also sought to explore how power acts on the subject to make the subject possible and what is taken up and reiterated in the subject's own acting. The journey to Macau cannot be broadly assigned as a 'pure' phenomenon as though they were 'uninfected' by culture and constituting processes and conditions (Søndergaard, 2002). Post-structural curiosity about the subjectivating processes, the constructions of cultural, political and social conditions and 'ambitions to transgress ahistorical and naturalized taken-for-granted' (Søndergaard, 2002, p. 189) understandings, served as the impetus to explore different discursive meanings. Categories, such as 'gaming tourists' have their own discursive boundaries, with politicians and Macau based academics promoting certain 'rational' and acceptable discourses and normative principles to the phenomenon of gambling in Macau. By way of a poststructuralist methodology, this study sought to challenge what is already 'known' about gambling tourists to Macau and challenge discursive boundaries. Exploring pilgrimage as a conceptual metaphor, which is a discursive construct, is done by way of the data, and based on the authors' analytical perspectives. Søndergaard (2002) argues that researchers must interpret the discursive practices he or she has access to. While there is criticism of conceptual metaphors, because of the subjectivity involved in the interpretation, the authors sought to connect small specific contexts, conversations, incitements, interviews, collective undertakings, activities, rituals, public documents, observations and newspaper articles. Putting deconstruction to work, this study sought to think against the stream of what is taken for granted and make 'partial connections' between different constellations, processes and storylines. The authors sought to explore and link frameworks of available metaphors and discursive categories to the events, moments and actions described by informants and the sociocultural and subjectivating phenomena the authors observed (Bonham \& Bacchi, 2017). As stories of bodies, play, superstition, casinos, risk and spatiality emerged; the authors came to explore the journey to Macau as a purposeful, somewhat arduous, ritual journey to a place of sacred significance. The study reached saturation at the point when the authors began to know the data, were familiar with it and with an analysis which makes visible a socio-cultural discursive reality (Aldiabat \& Le Navenec, 2018; Taguchi, 2012). The analysis makes visible new thought lines about how 'people, places and pasts are conceived, constructed, and valued' (Hollinshead \& Jamal, 2001, p. 61). The study therefore came to challenge the categories of pilgrimage and gambling tourism, and Western ideas of what constitutes typical behaviors in those categories. While pilgrimage is a 'comparative concept' (Clifford, 1997) and acts as a metaphor of movement and flow within post-structuralist analyses, our dynamic, open-ended analysis generates newness to our understanding of a specific pilgrimage in China. The study uses quotations from informant stories to provide illustration.

\section{Liminal and transformative space}

Whether travel has been undertaken for noble, pious, pure, impure reasons or just plain curiosity, relaxation or self-development (e.g. to bond with kin, to make money, to avoid debts), the informants journeys combined 'freedom from' the immutable 
(constrained) environment of mainland China, with its economic pressure, rigidly and corruptions and 'freedom to' a new symbolic world (Turner, 1974b) which is transformative. Macau and its casinos represent something special (sacrality of space), with informants recognizing Macau as a 'place on the margin,' with participants 'betwixt and between' two social worlds (Turner, 1969, p. 107). The respondents described Macau as a golden city, a miraculous city, a clean and ordered city, which allows the fulfilment of desires and fantasies. Informants were found to negotiate their visit to Macau by way of ritual knowledge, with timing particularly important (sacrality of time). Jane, 42 explained how she had a friend who accompanies her to Macau. She notes that and 'when her left eye has eyelid tremor, it means there is going to be an opportunity to make money, according to Chinese folklore.' Therefore, she only visits Macau to gamble when her friend has an eyelid tremor. Nick, 47 and self-employed argues that 'I think everyone has his/her luck, and it can be weak or strong at different times.' Jenny, 55 notes how her visits coincide with the Chinese zodiac. Jane and Martin, 25 also strongly believed in staying away during unlucky periods, with Martin noting; 'I think if people are really unlucky during a specific period, they will lose a lot when gambling.' Jenny, 55, notes:

If I am really in bad luck, I will just stop gambling for a while. Chinese people may have conflict with a particular animal year and they will be very unlucky during that period. If I have conflict with a particular animal year, I will not plan to visit Macau to gamble because of the greater possibility of losing money.

The informant's desire and agency to confront fate and escape from everyday mundane social roles, structures, hierarchies, identities and realities was evident in their stories, as well as vivid emotions from excitement to anxiety. The informants were faced with various issues such as getting a visa and seeking currency during a time of strict capital outflow controls. This voluntary embrace of a pilgrimage to Macau is experienced through ritual (symbolic) aspects rather than 'belief' given such rituals can reference or take the form of a journey as well as objects, activities, words, relationships, events, gestures, or spatial units (Turner, 1967). The potentially transformative ritual journey begins in the form of a concrete, bodily separation from mundane social structure, hierarchies and identities such as mother, wife, husband or student. Turner (1974a, p. 260) notes that the social need for escape from or abandonment of structural commitments seeks cultural expression in ways that are not explicitly religious, though they may become heavily ritualized.' The informants generally did not identify the trip as fun, or the activity of gambling as entertainment. Gambling was repeatedly linked to self-achievement and testing one's luck. Peter, a student and Jackie, 52 noted that the journey was about testing one's luck and knowing how lucky they were. Martin noted how 'a proper attitude to gambling was very important.' Nick noted that 'I will only concentrate on gambling, and I think that one important criteria to win when playing table games is luck but also intelligence.' The informants did indicate that the journey was always uncertain, given the limited opportunities to visit Macau. Neighbouring Guangdong province, for example, limits individual visits to Macau to once every two months. Macau and its casinos are 'set apart' from the workaday world, with Jane noting that in Macau, '[e]verything is unknown and uncertain, and you don't have idea about what are going to happen.' Despite gambling advertisements been banned in 
the mainland (Tang \& Wu, 2010) and any casino representatives who proselytize casinos at risk of arrest, Macau had an incredible pull on the informants. This was because daily social norms are suspended, and they are permitted adventure, fantasy, and pleasure by taking up an anti-structural position (Turner, 1982) in a space where Dionysian indulgence (gambling, shopping, legalised prostitution) is encouraged (Sacramento, 2011) and symbolic, cultural and spiritual rituals are enacted. For Jenny:

I go to worship regularly and wear an amulet. I will read books about Chinese zodiac horoscopes before I go to gamble, to know about which my lucky position is, for example, east or west, or what my lucky colour is. Then I will try to wear clothes in corresponding colour. What's more, I have a friend .... [who] tells me which crystal can create luck in making money or which crystal can counteract evil forces.

Martin noted that his girlfriend asks him to wear red underpants if he is going to gamble, as she believes that it would make him luckier when gambling. Jane never goes to the toilet before gambling, noting how 'peeing can be understood as 'drawing off water from your body' in Cantonese, which also means losing something. Jane goes onto say that:

I believe in luck and fortune. I usually don't go to temple and pray, but I have to wear my bracelet which made by citrine [which the informant believes brings money making luck]. I will avoid to wear black if I am going to visit Macau to gamble, because for me black means bad luck when gambling.

\section{Casinos as Sacred Places}

This study re-emphases sacred space with the phenomenon of pilgrimage (Dewsbury \& Cloke, 2009; Maddrell \& della Dora, 2013; Megoran, 2013; Tse, 2014). Little scholarly attention has focused on how the spiritual is made manifest, with Kong (2001, p. 213) noting that 'if sacredness is not inherent, attention must be paid to how place is sacrilized.' The mainland visitors interviewed enter Macau through either the two border gates, one of the two ferry terminals or the airport. After disorientation, confusion and a loss of their sense of self that comes with the lengthy immigration and custom checks, the informants are met with young 'uniformed marshals' (Moore, 1980, p.214) from the various casinos, dressed up in bright regalia (see figure 1). Nick, 47 notes how 'I have to apply for visa to Macau, exchange currency, but I don't have to prepare too much for transportation as there are shuttle buses to different casinos in Macau.' The casino buses bring them to the liminoid space of casinos (Turner, 1969), with Comaroff and Comaroff (2000, p. 295) describing them as 'liminal places of leisure.' Jenny chooses which casino to visit based on her lucky colour, with each informant listing sacred places in terms of contrasts, similarities and degrees of manifest powers. Jenny notes how 'I don't have any lucky casino, but I will choose casino according to my lucky colour. For example, I may go to Wynn [casino] if the book mentions my lucky colour is red, or I may go to Galaxy [casino] if it is yellow.' She went on to note that:

Usually I will observe the FengShui of different casinos. For example, I seldom go to the old Lisboa [casino], because people say the design of its main entrance looks like a tiger opening its big mouth, which means throwing chum to sharks when people get into it. Besides, the 


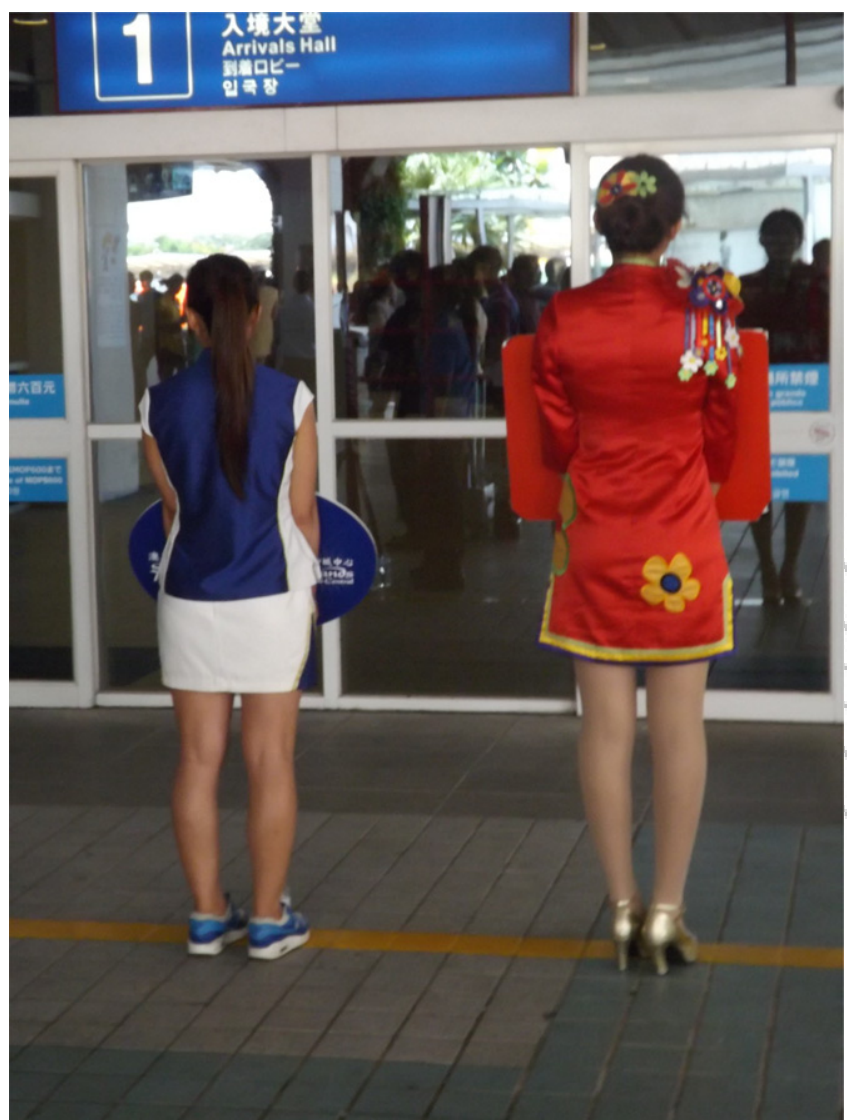

Figure 1. Waiting for passengers at the Macau Outer Harbour Ferry Terminal. Source: Authors. Used with permission.

architecture design of old Lisboa looks like a birdcage and it means people will be trapped in it like birds after they get into the casinos and start to gamble.

The Venetian casino, for example, is a US\$2.4-billion replica of the Las Vegas Venetian, which in turn is a replica of Venice. Like entering a giant limen, one has to walk over a bridge to enter. This leads directly to the largest casino floor in the world, in the second-largest casino in the world. With extensive visible depth, high ceilings and excess décor, the casino is bright, airy and designed to reflect FengShui rules (Buzinde, Choi, \& Wang, 2012) so as to function as a place that possesses divine power thus serve as centre of communication and interaction with divine forces (Singh, 2009).

The casinos use iconographic representation of sacred mythologies and Chinese cultural themes such as the Buccleuch Vases at Wynn Macau casino, Wishing Crystals at Galaxy, and two animal heads representing the Chinese zodiac looted from Beijing's Old Summer Palace in 1860 at the Lisboa. Novel sights, light, sounds, tastes and smells are designed to evoke awe, wonder, fear, power and ultimately offer both corporal inspiration and eternal satisfaction by superimposing beliefs and incorporating ritualization processes. Walter (1988, p. 75) writes sacred places 'organise sight and sound, introduces light to present clarity and order, or makes things dark to suggest unseen presence and 
hidden power'.) In these sacred places, with no windows, no clocks, etc., time is never exhausted (Eliade, 1967). During this sacred and indestructible time, casinos present beauty and power with both aesthetic and intrinsic values to create potentials, perspectives and associated performances. Unlike American casinos, there are few slot machines with flashing lights or synthesized sounds. There are no bachelor parties, music, alcoholic drinks, fast music or scantily dressed staff to heighten the perceived level of excitement (Plate, 2009). Waitresses push trolleys and offer free water, orange juice and green tea around the sea of baccarat (primarily 'puntobanco') tables which dominates the floor and 90 per cent of Macau's gross gaming revenue. For Jane, table games are easy to learn, and need the cooperation of each player at the same table. For Nick:

I prefer table gambling with more people. The atmosphere around me during the gambling experience is usually very lively, which can give people a sense of excitement. I like the table with more people, because I think that means more prosperity.

These table games were favoured by all the informants, with playing cards a totem of a faith. In theory, the result is determined as soon as the cards are dealt. However, the informants believe their chance of winning is increased when they throw the dice or draw a card themselves. While each described their own technique, a common approach is informants touching, squeezing and slowly 'peeking' at their dealt cards by peeling (bending) them upwards so as to look for clues about what the face value might be from the shapes on the edge. By shouting, touching, feeling, bending and blowing (away unwanted numbers), the informants feel they are in control of the game, with pilgrimages profoundly bodily as 'one moves physically through space to seek the physical presence of, if not contact with, the sacred' (Wheeler, 1998, p. 6). All informants shared stories of some notion of bodily devotions. Some described pounding on the table in the belief it would give their opponent a face card and bust their hand. Others indicated that they stand around the tables to see patterns in play before deciding to join in. As the gambler is a vehicle of Providence... a vehicle of precognition' (Neveu, 1967, p. 459 in Papineau, 2005, p. 167), players who notice a 'lucky' (or unlucky) player winning (losing) consecutive hands can side bet on the player. Gamblers may suddenly abandon a table and rush towards another where a lucky player resides. Nick notes how '[d]ifferent people have different luck, and they may influence each other's if they play together.' While Nick sometimes enjoys playing alone, he followed lucky players when he felt his luck was bad:

Usually I prefer to play alone, so that my luck will not be influenced by others. If I find that I am not very lucky at a specific time, I will change table or bet by following other people who are strongly lucky at that time.

Martin noted that:

If I feel that I am unlucky when gambling, I will not bet and just stand there and watch my friends' play, or I will just bet with those people who are really lucky during that period.

The casinos are containers of ritual activities as they promote a 'microscopic battle' (Lam, 2007) where seriousness and playfulness combine in public between science and faith, with the performed gestures and 'acting up' part of the indissoluble connection between sacred earnest and 'make-believe' (Huizinga, 1950, p. 24). While the casino can reliably calculate its advantage to two decimal points, the informants rely 
on a combination of fate as well as earthly and supernatural skills (Basu, 1991). The extremity of the situation renders participants decidedly equal with 'unprecedented modes of ordering relations between ideas and people become possible and desirable' (Turner \& Turner, 1978, p. 3). 'Communitas' means the gamblers relate to one another independent of social categories as they shift into spontaneous social bonding in a contained space considered safe, egalitarian and divine.

\section{Temple Festivals}

The rituals surrounding gambling creates a bridges across social divides to divine realms and a festival like atmosphere that can be likened to a traditional Chinese 'Temple Festival' (Ward, 1979). Gambling had a sanctioned role in such festivals (now largely banned in mainland China), since they provided economic benefits for local communities. They were a special time marked off from ordinary time as people could do things they would not normally do. At these gatherings, people ate, drank, shopped, smoked, gambled or simply watched, so as to be 'part of the scene' (Chau, 2006, p. 155). Rather than competitors in a 'market for hope' (Lutter, 2011), as might be the case in the West, religiosity was a significant factor in facilitating popular participation in gambling (Ho, 2006). Common elements to both include notions of chance, fate, uncertainty and risk as well as imagery of receiving a reward that changes life for the better (Binde, 2007; Gabb 2001; Papineau, 2005). Gamblers made offerings to the gods 'in order to allow the god to enjoy their spiritual essence' (Ward, 1979, p. 24). Just as in a temple festival setting, the casinos are designed to conform to 'the correct geomantic orientation is also necessary in order to secure proper alignment with cosmic forces and to ensure their full, auspicious flow' (Ward, 1979, p. 28). The pilgrims play all day and night, 'in ritual time and ritual space, in other words in symbolic time and space' (Ward, 1979, p. 25). Casinos are whole, permanent institutions rather than ephemeral, with informants explaining how they conspicuously made offerings which they hoped would be multiplied and returned. The informants felt that by 'giving,' they would receive wealth in return. Jenny felt by donating money to casinos via 'wishing wells,' one might get a return from the casino. Nick noted that by donating money to people or charities on the streets, 'good luck will come to you if you do enough good deeds.' Jane noted that; 'I must not enjoy the free meal [from the casino] before gambling, because if I eat their free meal first, it means I have to give back something to the casinos later, and that is losing money.'

The temporality of space-time makes gambling time dense and trance like. Kairos time lives outside the bounds the time we know via our clocks and means time passes effortlessly (Sipiora \& Baumlin, 2002). Gambling aids in the step away from the temporal world into the sacred one. None of the informants spoke of succumbing to bodily needs even as they told stories of staying up 24 hours straight gambling to risk one's well-being (health, safety, money, etc.) in exchange for divine intervention. Informant stories emphasised their active participation in a social sensorium (Chau, 2008). Although crowds push and shout and stimulation as hysteria 'literally assault and saturate the senses of the worshiper' (Hau, 2006, p.162), such rituals have been noted in Chinese ethic communities who gamble in Taiwan (Harrell, 1974) and around 
the globe (Basu, 1993; Choong, 1983; Papineau, 2005). As gamblers produce and experience 'red-hot sociality' (Chau, 2008), the noisy, excited 'bustling crowd' is held to bestow a highly auspicious blessing (Ward, 1979). Gambling is rarely imagined and performed without others, with Huizinga $(1955$, p. 13) describing play-mood as one of rapture and enthusiasm. Singh (2009, p. 251) describes an identity quest at sacred places as 'a public performance and an open ballet in which overseers and devout spectators play their own role.' The embodiment aspect of ritual (and the senses) sees the body enacting cultural meanings. Ritualization occurs 'through the interaction of the body with a structured and structuring environment' (Bell, 1992, p. 98). Spectacle, 'heat' and ritual structure the environment and the bodily experience, where ritualized bodies with changed attitudes towards time, belief and the quest for self-transformation are invested with a 'sense' of ritual. Gamblers challenge a mysterious 'other' (fate, chance, and luck) to produce sociocultural situations that the ritualized body can dominate in some way (Fieldman, 2017). While gamblers have differing needs and intensity of belief (Wheeler, 1996), all those at the casino tables perform rites, ritual speech, and choreographed movement.

\section{Power and Control in Pilgrimage}

Casinos operate a system of practices and rituals in relation to sacred things as culture, history and religiosity are discursively commodified for performance (Buzinde et al. 2012). While sacred places in Macau, such as community temples, were often used by both the Portuguese and Chinese authorities to serve their own national interests, the development of new forms of ritualistic sacred spaces does not imply a retreat into tradition. These casinos are granted new symbolic value, as rituals - as performances - become rearticulated as acceptable social dramas. They are intentionally shaped to work at various levels of social organisations from individual to cultural group. The opportunities for monetization and commercialization ensure that pilgrimage is a ritual form 'most susceptible to appropriation by commercial, secular interests' (Moore, 1980, p. 216). In Macau, rituals are manipulated in a symbolic economy by non-state transnational actors, officials and investors. These actors have materialized their vision of a transformative (and profitable) aesthetic of pilgrimage by (re)inscribing and (re)articulating rituals through the expertise of designers, architects, creative advertisers, consultants, marketers, psychologists and IT specialists. The concept of miracles and 'salvation play' in the pilgrimage experience is a recurring theme with informants, with most noting the possibility of a psychosomatic transformation breaking through into everyday through miracles (e.g. gaining unexpected wealth).

Macau casinos use staff uniforms (as ritual garments), monuments, paintings, performances, statues, festivals, ceremonies, membership schemes and an array of symbols as emotional stimuli and even create stories, folktales, legends, myths and legends to guide performances. These ritual inducements coexist with a highly developed scientific world that seeks to extract maximum revenue per available customer by enabling transitional conditions through liminalization (Schüll, 2012). As casinos focus on desires that can be validated through the aesthetic of a playful pilgrimage, the resulting mishmash of rituals communicate fate and luck, protection and success, 
security and prosperity and tradition and modernity. Appropriated from earlier forms, the rituals are formed to suit the culture and incite a response as gamblers co-construct meaning around Macau and particular casinos. While the Chinese Communist Party (CCP) 'battles' a growing trend of religiosity, China remains a 'religious state' (Lagerwey, 2010), given that religiosity incorporates a wide range of ritual practices that might include fortune telling (numerology, physiognomy, graphology, palmistry, fengshui, geomancy, face reading and Bazi), good luck charms, magic, shamanism, deity and ancestor worship, exorcism, demon and ghost worship, polytheism, ritual healing and communicating with the dead (Yang, 2011). Diffused, non-exclusive and pluralistic rituals are designed hope is to gain favour for endeavours in this world and is therefore predominantly linked to the economic and the personal (Bosco, Liu, \& West, 2009, Steinmüller, 2011). Jenny notes:

There is a huge red crystal chandelier in main entrance of Wynn, and some people say it works as western magic to confuse gamblers and make them play badly when gambling. However, some experts in FengShui say there is a way to beat it, which is walking into the casinos by touching the wall so that you can bypass the red crystal chandelier.

There are repeated stories of symbols and buried animal bones linked to particular casinos, which connect them to the supernatural power of animatism, FengShui geomancers and 'numerological mysticism' (Needham, 1995). Walter (1988, p. 117) suggests that the quality of a place depends on memories and expectations, 'by stories of real and imagined events - that is, by the historical experience located there.' Casinos balance the ritual-liminal forms of ritual heritage with industrial-liminoid forms as they facilitate, evoke and mimic culturally familiar rituals to enhance a person's perceived self-efficacy, sense of control and self-confidence, whilst reducing anxiety and stress (Damisch, Stoberock, \& Mussweiler, 2010). They call forth certain thoughts, beliefs and ritualistic behaviors using multivocal and supernaturally charged symbols which are anthropological, metaphysical, historical and cosmological. These evoke narratives already known to the informants, and are articulated as vital knowledge. The admixture of 'idiosyncratic and quirky' (Turner, 1979, p. 493) symbols are playful but richly textured, dramatic symbolic vehicles that give many rituals a metaphysical dimensions and processual armature (Turner, 1980). As many informants remained in one casino during each trip, they submit to the ritual performances, which nearly always 'accompany transitions from one situation to another and from one cosmic or social world to another' (Van Gennep, 1960, p. 13). Such rituals prepare the organism to act, transforming them from irrational creatures of desire into extremely efficient gamblers seeking to understand mysterious modes of accumulation. These symbolicvehicles meld old and new, elite and popular culture, east and west, invented pasts and futures to the specific and the vague. They evoke the mythic-heroic past by using technology and special effects to make them 'sensorily perceptible' (Turner, 1982, p.27). The 3meter tall Fortune Diamond (see figure 2) located in the hotel lobby of Galaxy Macau is based on the plumes of the peacock, and symbolizes prosperity and good fortune. The Wynn casino has a mechanical and multimedia Golden Tree of Prosperity (see figure 3) and a Dragon of Fortune whose centerpiece depicts Chinese and Western astrological symbols. As a symbol of prosperity and luck, crowds will throw coins and wish for good fortune. Participation in ritual processes can take multiple meanings as gamblers co-construct meaning in rituals where metaphysical prototypes and heavenly patterns of material 


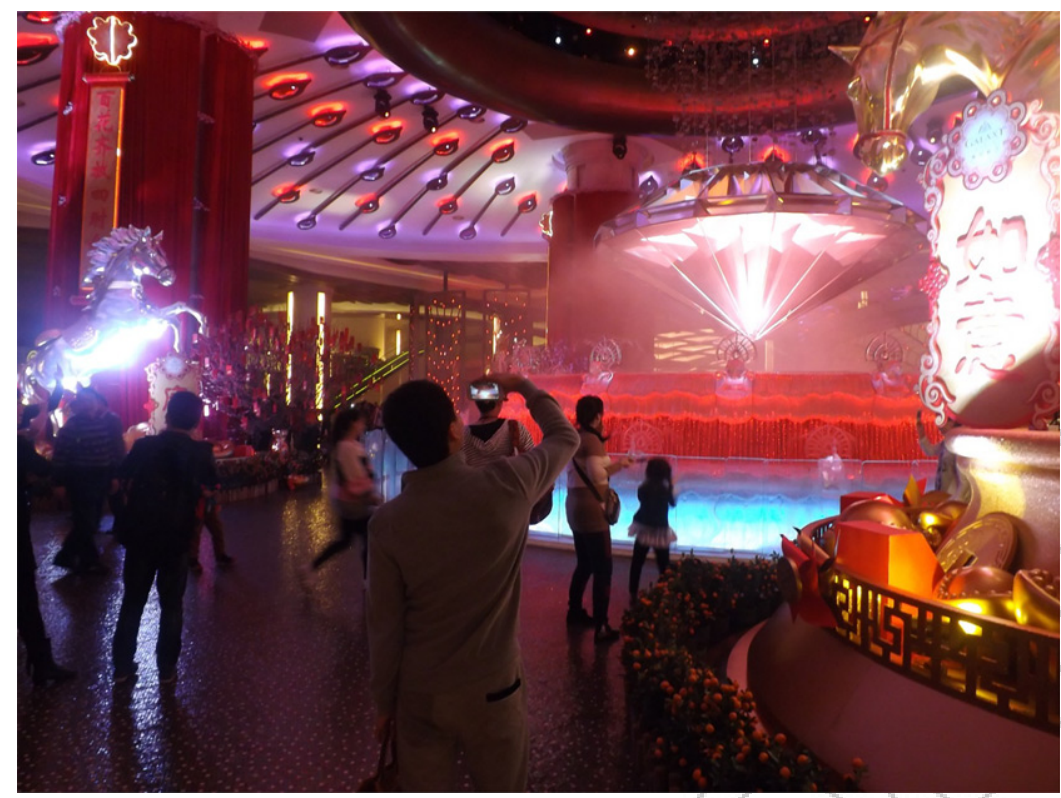

Figure 2. Fortune Diamond. Source: Authors. Used with permission.

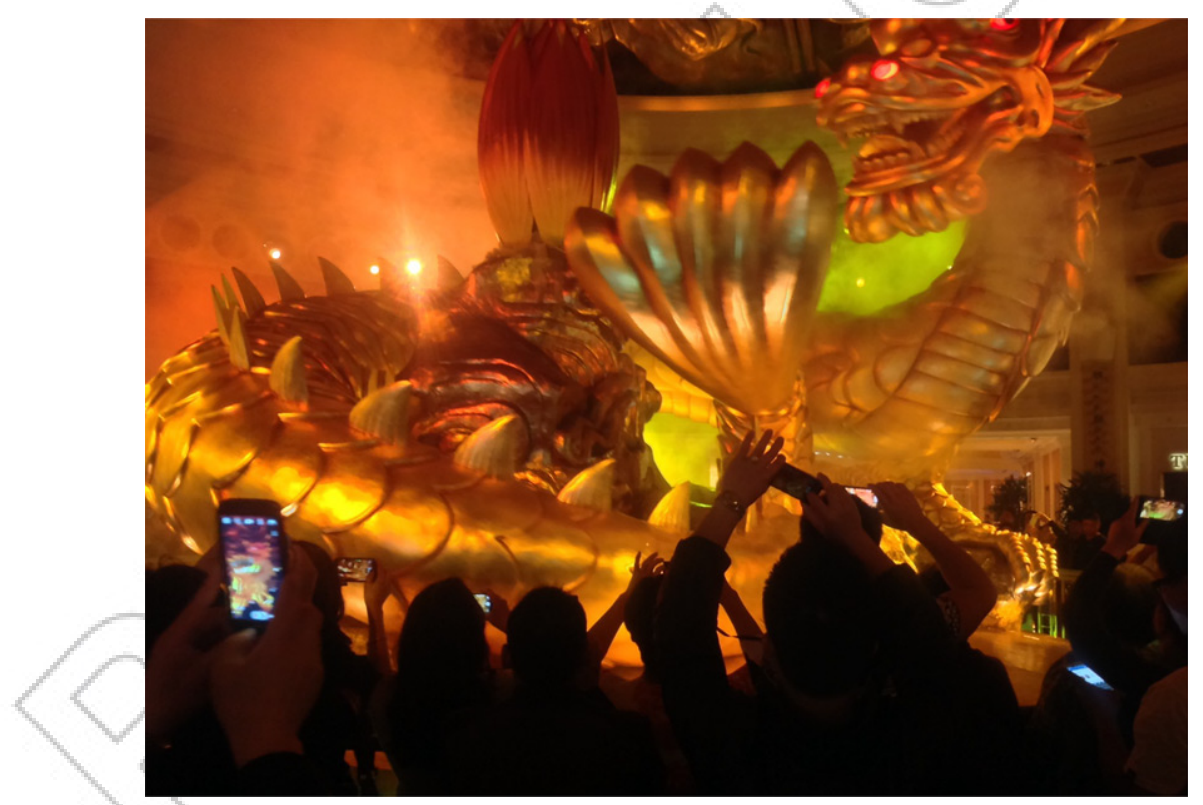

Figure 3. Golden Tree of Prosperity. Source: Authors. Used with permission.

things meet (Singh, 2009). Situational belief (Coleman, 2014), means those sites can either be a good 'selfie' to a ritual site where coins and bills are purified and invested with divine qualities. We argue that 'pretence-ridden liminality' (Driver, 1998, p.160) has substance and plays an important role in sacred places by creating variety of patterns, relationships, interactions, meanings between participants and the divine realm (Singh, 2009). For Jenny: 
In Macau, I may visit the dragon or tree at Wynn if I am going to Wynn to gamble, I may throw a coin to the dragon or tree when they come up before gambling, and that means I already give something to them, and they have to return something to me later. For example, to let we win money when gambling.

Any failures or destruction associated with the pilgrimage are hidden, as the rituals which displace feelings are validated 'at the cost of preserving the general unreality which it obscures: the real failures of society' (Williams, 1980, p.189). Gambling addictions were never addressed by informants, along with any unresolved dilemmas, such as loneliness, frustration, and the search for identity. Such tensions are condemned and even censored when it spills out from Macau into other areas of life (Basu, 1991). The magic of symbolic vehicle apparatuses celebrate blind ritual behaviour that motivates gamblers to persist at tasks when they might otherwise give up. Casinos are a by-product of rational materialism, with its owners cementing new meanings, myths and rituals in their buildings. They hope to foster a bond between people and place and serve as repositories for collective memory. The practice of ritual actions produces new layers of meanings embodied in the materiality of casino temples, as they 'inculcate certain values and norms of behaviour by repetition, which automatically implies continuity with the past' (Hobsbawm \& Ranger, 1983, p.1). This study argues that the rituals taking form in the pilgrimage to Macau are being wrestled free from ritual contexts as casinos market cultural resources and experiences through a form of 'tourism' approved by Beijing. The pilgrimage is built on the 'organization of symbols or rituals that carries the pilgrims through the ambiguity and risk of a world of symbol and myth' (Holmes, 1976, p.126) and makes them vulnerable to exploitation by way of deliberate, symbolic mechanisms. In such a context, Macau's cultural resources risk over exploitation and depletion at the hands of commerce as ancient beliefs are appropriated, without authorities fully questioning the consequences.

\section{Pilgrimage as a release valve}

Gambling is associated with irrationality and corrupt practices in the mainland, with the socio-political order viewing it as a threat. While they have come close to eradicating it through legal sanctions, the pilgrimage to Macau is assigned to a different realm by Beijing. Its playful, temporary nature and ritual levities means it is sanctioned as long as it remains contained. The rituals in the journey to Macau compensate for the lack of other forms of effective societal control in China such as bonds of religiosity or kinship. Given the 'restorative quality implicit in ritual play' (Raj \& Dempsey, 2010, p.7), the pilgrimage to Macau is a socially sanctioned outlet for managing potential crises and change. As a ritual, gambling functions as a release valve where excess energy is released and facilitates the contradiction 'between superstitious belief or hope in luck and the upright thrifty values promoted by Confucian and equally by communist teaching' (Kelen, 2009, p. 41). The concept of Chinese citizenship, governance and society underlines discipline, order, planning, predictability, central control and accountancy and obedience to external demand, so as to keep a country of over one billion people together. The participation in playful defiance helps to reinforce those values and the significance of the status quo (Raj \& Dempsey, 2010). Rites of 
intensification are rituals that increase group solidarity, and reinforce commitment to the beliefs of the group. The rites seen during the pilgrimage and at the casinos seek an emotional response as basic beliefs and sentiments are focused upon and experienced anew. Integral to one's mental and biological health (Di Giovine, 2009), the rituals periodically refresh and renews the social order.

Given that work and leisure are complementary parts of the same living process in China (Schumacher, 1973), this study leads us to disagree with Huizinga who views gambling largely as sterile, unproductive and dispensable to culture. Furthermore, the pilgrimage is produced and given meaning within relations of power, with the journey to Macau strongly related to mainland law, policy and the conditions of pilgrimage (i.e. immigration provisions). China, we argue, sanctions it as long as the pilgrimage is not seen as contrary to the approved social scripts in everyday life. It is a sanctioned way of safely 'letting off steam' (i.e. from the overdose of social order in the mainland). It also allows a means of inducing citizens to learn from being disorderly or 'new paradigms and models which invert or subvert the old' (Turner 1979, p.474). The pilgrimage stimulates and releases the excess energy of millions, so as that their sacrifices can be transmuted through a marathon orgy of compulsive spending and acquisition. However, given such excess, the pilgrimage is breaking through the boundaries in which it is usually confined. Unrestrained, it 'becomes a symbol not of the interplay of fate and control, but of total failure and lack of discipline' (Basu, 1991, p. 249). The CCP has shown its displeasure at excesses (e.g. gambling by corrupt officials) or communitas breaking into society to attack the social structure. The contained exorcism at the margins is accepted, only if it ensures national stability and sustains periodic renewal. The pilgrimage only works because it offers visitors freedom (e.g. hotel registrations data is not shared to entities outside the MSAR) and the ability to engage in activities that are illegal in China. It enables individuals to withdraw out of view and become to some degree detached from everyday roles and structure (Di Giovine, 2011).

However, freedoms and license are threatened by intensive degrees of surveillance and control by way of ubiquitous surveillance cameras, paid informers and plain clothes security agents in Macau. Plans for the installation of public CCTV cameras, facial recognition and data sharing with Beijing may upset the mutual inter-dependent relationship between casino, local people, gamblers and the MSAR government. If the superimposition of sacrality becomes regulated by counter-rituals imposed by Beijing, the restriction of gamblers as active explores and negotiators of societal possibility may bring more control, but also new tensions as they return to their daily lives (Henricks, 2011). However, while casinos are being built in Vietnam, Cambodia, Taiwan and Singapore with similar 'pull' factors for Chinese gambles, Macau's liminality and marginality have generated lasting myths, symbols and rituals worth sacrificing for.

\section{Discussion: Reconceptualisation of the Pilgrimage concept in modern China}

This study found pilgrimage to be a productive metaphor to describe the journey and experiences of gamblers to Macau. While the study does not characterize all travel to Macau as movement towards sacred space as individuals have private and often 
competing desires, drives, and identities, the study did find Macau to be a free, liminal zone for informants. The study also found casinos to be sacred places, where a festive sociality ensures a community of 'collective joy' (Turner, 2012) and timeless absorption. This study not only locates an active, modern pilgrimage in modern China, but also reconceptualises the pilgrimage concept by transgressing the oppositional categories of the religious and the secular in the literature. While the distinction between tourism/pilgrimage, tourist/pilgrim, and secular/sacred is complex (Di Giovine, 2011; Badone \& Roseman, 2004), the study highlights how competing discourses can coexist and be concurrent (Wheeler, 1998). This study utilised storylines about moving, thinking, feeling and doing into objects of study to conclude that the tourist-pilgrim dichotomy does not exist (Pfaffenberger, 1983) as pilgrimage and tourism may be conceptualized as 'two parallel, interchangeable lanes' (Smith, 1992, p. 15). Whilst accepting that there may be no single underlying truth, the study argues that for informants, the pilgrimage and sacred space are not secondary to 'tourism' given it is produced through pilgrimage and ritual systems. The use of the pilgrimage framework as a conceptual metaphor finds euro-centric descriptions of tourists as (secular) pilgrims in a quest of authenticity (Graburn, 2001; MacCannell, 1976) lacking in the Macau context.

The study highlights that pilgrimage is a complex and varied human activity, with western understandings not equally applicable to the Chinese setting. While the study uses the euro-centric body of pilgrimage knowledge and extant research, it also draws heavily on Chinese religious and pilgrimage history. While Macau's success is often put down to the extent to which visitors are drawn to a secular destination with integrated resorts to engage in individualistic activities, the manifestations of culture, governmentality and intentional ritualization should be central to future research. The study argues against universalizing the relevance of historical contexts, and cultural meanings to other communities and practices, given Macau is an anchor, with its sacred places possessing 'manifestive power like spirituo-magnetism that always get re-awakened by rituals' (Singh, 2009, p.231). The iconicity of a metaphor 'depends on cultural codes, and cultures themselves vary, there can be no universal metaphors' (Dann, 2002, p. 1). This study provides us with an understanding of how Chinese culture and cultural tradition is preserved in the present, with symbolism, mythology, and intentional ritualization processes interwoven into journeys and spaces. The study reveals the intentional ritualization that surrounds the informants and enables them to enter, co-create and tolerate liminal conditions. By considering the significance of political and commercial dimensions, the study identified how rituals are embraced articulated, harnessed and optimised. The study also identified the linkage between the political, economic and spiritual spheres and elements of power and control in the release valve of pilgrimage.

Furthermore, this study found that in a Chinese context, play takes on much of the organized ritual form of the pilgrimage, with the 'ludic' or playful elements now doing the serious work of ritual (Huizinga, 1955; Turner, 1974). The notion of play has often been forgotten in western contexts as an essential aspect of the liminality of pilgrimage, with Turner (1967) specifically using the concept of 'liminoid' or 'ludic liminality' rather than liminal to describe liminoid experiences that are closer to play. A playful 
pilgrimage doesn't deviate from notions of pilgrimage as involving rites (Van Gennep, 1960), liminoid behaviour, ludic capacity and sacred space, and retains the notion of pilgrimage as giving license to behaviour beyond and outside conventional norms of propriety. A pilgrimage may also involve 'deep play' (Geertz, 1972). Despite being playful, the study finds gambling is passion-laden deep play, hyper-meaningful, steeped in symbols and symbolic actions (Di Giovine, 2011), as well as situated within 'accrete[s] rich superstructures' of mythological representations (Turner \& Turner, 1978, p. 23) and ritual (Tsang, 2004). Indeed, the playfulness partially comes from the sense that the social structure is just one step behind.

More broadly, the study draws us away from euro-centric studies that point to gamblers distain of rituals (Shalin, 2016) and its characterisation as sterile and unproductive. While Huizinga (1955, p. 13) argues that gambling was dispensable to culture, given it is 'connected with no material interest, and no profit can be gained by it', the study argues that this is not true within Chinese society where fate and fate control is manifest in liminal conditions (Langer, 1975; Leung \& Bond, 2004; Presson \& Benassi, 1996; Sangren, 2012) and where gamblers are not seen in pejorative terms. Future research should explore other pilgrimages in China at the centre of (geopolitical) conflict (Zhang, 2017) and as they manifest as more controlled political pilgrimages (Li \& Hu, 2008).

\section{Conclusions}

The study found a ritual path of pilgrimage interwoven in the storylines and practices of mainland gambling tourists to Macau. The role of movement, the body, play, time and space scarcity, hyper-meaningfulness, intentional ritualization, risk-taking and sacred spaces was explored within a particular geographic, political, social and cultural context that derives from Macau's position as a liminal space (and time) marked by sacred places, temple festivals and kairos time. By linking gambling tourism by mainland Chinese with pilgrimage contributes to our understanding of geographies of pilgrimage in an understudied context. The study takes into account meanings, practices, relationalities, spatialities and subjectivities to study a pilgrimage outside a Western context. We found gamblers are moulded in a process defined by their interactions with others, the material environment, the commercial, cultural, political and spiritual spheres as well as unique discourses of power and control that affect the release valve of the pilgrimage.

\section{Notes on contributors}

Michael O'Regan has a PhD from the School of Sport and Service Management, at the University of Brighton, United Kingdom (2010). His research interests are slow, alternative, historic, future and cultural mobilities, and Chinese Tourism.

Jaeyeon Choe holds her Ph.D. in Tourism Management (Minor: Cultural Anthropology) from The Pennsylvania State University. Her primary research areas are religious and spiritual tourism and Chinese consumer behavior.

Michael A. Di Giovine is an anthropologist and former tour operator whose research in Europe (Italy, Spain) and Southeast Asia (Vietnam and Cambodia) focuses primarily on heritage discourses and practices, global mobilities (tourism/pilgrimage/diaspora), religious movements and cults, development and revitalization, and foodways. 


\section{References}

Aldiabat, K. M., \& Le Navenec, C. (2018). Data Saturation: The Mysterious Step In Grounded Theory Method. The Qualitative Report, 23(1), 245-261.

Badone, E., \& Roseman, S. (2004). Intersecting Journeys: The Anthropology of Pilgrimage and Tourism. Urbana-Champagne: University of Illinois Press.

Basu, E. O. (1991). Profit, Loss, and Fate: The Entrepreneurial Ethic and the Practice of Gambling in an Overseas Chinese Community. Modern China, 17(2), 227-259.

Basu, E. O. (1993). Blood, Sweat, and Mahjong: Family and Enterprise in an Overseas Chinese Community. Ithaca, NY: Cornell University Press.

Bell, C. (1992). Ritual Theory Ritual Practice. New York: Oxford University Press.

Binde, P. (2007). Gambling and religion: Histories of concord and conflict, Journal of Gambling Issues, 20, 145-165.

Bonham, J., \& Bacchi, C. (2017). Cycling 'subjects' in ongoing-formation: The politics of interviews and interview analysis. Journal of Sociology, 53(3), 687-703.

Bosco, J., Liu, L. H-M., \& West, M. (2009). Underground lotteries in China: the occult economy and capitalist culture, Research in Economic Anthropology, 29, 31-62.

Braun, V. and Clarke, V. (2006). Using thematic analysis in psychology. Qualitative Research in Psychology, 3(2). pp. 77-101.

Buzinde, C., Choi, Y., \& Wang, A. Y. (2012). Tourism Representations of Chinese Cosmology: The Case of FengShui Tourism, Annals of Tourism Research, 39(2), 975-996.

Chau, A. Y. (2006). Miraculous Response: Doing Popular Religion in Contemporary China, Stanford: Stanford University Press.

Chau, A. Y. (2008). The Sensorial Production of the Social. Ethnos: Journal of Anthropology, 73(4), 485-504.

Chen, H-F. (2017). Catholics and Everyday Life in Macau: Changing Meanings of Religiosity, Morality and Civility. London: Routledge.

Cheng, C. M-B. (1999). Macau: a cultural Janus. Hong Kong: Hong Kong University Press.

Choong, K. C. (1983). Chinese Divination: An Ethnographic Case Study. Singapore: National University of Singapore.

Coleman, S. (2014). Pilgrimage as a trope for the anthropology of Christianity. Current Anthropology, 50, 281-91.

Coleman, S. and Elsner, J. (1995). Pilgrimage: Past and Present in the World Religions. Cambridge: Harvard University Press.

Collins-Kreiner, N. (2016). The lifecycle of concepts: the case of Pilgrimage Tourism. Tourism Geographies, 18(3), 322-334.

Comaroff, J., \& Comaroff, J. L. (2000). Millennial capitalism: first thoughts on a Second Coming. Public Culture, 12(2), 291-343.

Damisch, L., Stoberock, B., \& Mussweiler, T. (2010).Keep your fingers crossed! How superstition improves performance. Psychological Science, 21(7), 1014-1020.

Dann, G.M.S. (ed.) (2002). The Tourist as a Metaphor of the Social World. Wallingford: CABI.

Dewsbury, J. D., \& Cloke, P. (2009). Spiritual landscapes: existence, performance and immanence. Social \& Cultural Geography, 10(6), 695-711.

Di Giovine, M. A. (2009). The heritage-scape: UNESCO, world heritage, and tourism. Lanham: Lexington Books.

Di Giovine, M. A. (2011). Pilgrimage: Communitas and contestation, unity and difference - an introduction. Tourism, 59(3), 247-259.

Di Giovine, M. A., \& Picard, D. (Eds.). (2015). The Seductions of Pilgrimage: Sacred Journeys Afar and Astray in the Western Religious Tradition. Farnham, Surrey: Ashgate.

Driver, T. F. (1998). Liberating Rites: Understanding the Transformative Power of Ritual. Boulder, CO: Westview Press.

Dwyer, C. (2016). Why does religion matter for cultural geographers?, Social \& Cultural Geography, 17 (6), 758-762. 
Dwyer, C., Gilbert, D., \& Ahmed, N. (2015). Building the sacred in suburbia: Improvisation, reinvention and innovation. Built Environment, 41(4), 477-490.

Eade, J. (1992). Pilgrimage and Tourism at Lourdes, France. Annals of Tourism Research, 19(1), $18-32$.

Eade, J., \& Sallnow, M. (Eds.). (1991). Contesting the Sacred: The Anthropology of Christian Pilgrimage, London: Routledge.

Eliade, M. (1967). Cosmogonic Myth and Sacred History. Religious Studies, 2, 171-183.

Feldman, J. (2017). Key figure of mobility: the pilgrim. Social Anthropology, 25(1), 69-82.

Gabb, D. (2001). Belief and value systems: Understanding all Australians. Electronic Journal of Gambling Issues: eGambling (online), 3. Website: http://www.camh.net/egambling/issue3/opinion/index.html

Graburn, N. (2001). Secular ritual: a general theory of tourism. In. V. Smith \& M. Brent (Eds.), Hosts and Guests Revisited: Tourism Issues of the 21st Century (pp. 42-50). New York: Cognizant Communication Corporation.

Geertz, C. (1972). Deep Play: Notes on the Balinese Cockfight. Daedalus, 101, 1-37.

Hall, J. M. (1997). Ethnic Identity in Greek Antiquity. Cambridge: Cambridge University Press.

Harrell, S. (1974).When a ghost becomes a god. In. A. Wolf (Ed.). Religion and ritual in Chinese society (pp. 193-206). Stanford, CA: Stanford University Press.

Hede, A-M., \& Hall, J. (2012). Evoked emotions: textual analysis within the context of pilgrimage tourism to Gallipoli. In. K. F Hyde, C. Ryan, \& A. G. Woodside (Eds.), Field guide to case study research in tourism, hospitality and leisure (pp. 45-60). Bingley, England: Emerald Group Publishing Limited.

Henricks, T. S. (2011). Caillois's 'Man, Play, and Games': An Appreciation and Evaluation. American Journal of Play, 3(2),157-185.

Herrero, N., \& Roseman, S. R. (2015). The tourism imaginary and pilgrimages to the edges of the world. Bristol: Channel View Publications.

Ho, V. (2006).Understanding Canton: Rethinking popular culture in the republican period. New York: Oxford University.

Hobsbawm, E., \& Ranger, T. (1983). The Invention of Tradition. Cambridge: Cambridge University Press.

Hollinshead, K., \& Jamal, T. (2001). Delving into discourse: Escavating the inbuilt power- logic(s) of tourism. Tourism Analysis, 6(1), 61-73.

Holmes, U. T. (1976). Ministry and Imagination. New York: Seabury Press.

Huizinga, J. (1955). Homo ludens: A study of the play element in culture. Boston Beacon Press.

Kelen, C. (2009). City of Poets exploring Macao Poetry today. Macau: Association of Stories in Macao.

Kong, L. (2001). Mapping 'new' geographies of religion: politics and poetics in modernity. Progress in Human Geography, 25, 211-233.

Lagerwey, J. (2010). China: A Religious State. Hong Kong: University of Hong Kong Press.

Lam, D. (2007). An Observation Study of Chinese Baccarat Players', UNLV Gaming Research \& Review Journal (online), 11(2).http://digitalscholarship.unlv.edu/grrj/vol11/iss2/5

Langer, E. J. (1975). The illusion of control. Journal of Personality and Social Psychology, 32, 311-328.

Leung, K., \& Bond, M. H. (2004). Social axioms: A model for social beliefs in multicultural perspective. Advances in Experimental Social Psychology, 36, 119-197.

Li, Y., \& Hu, Z. (2008). Red Tourism in China. Journal of China Tourism Research, 4(2), 156-171.

Lutter, M. (2011). Konkurrenten auf dem Markt für Hoffnung: Religiöse Wurzeln der gesellschaftlichen Problematisierung von Glücksspielen. Soziale Probleme, 22(1), 28-55.

MacCannell, D. (1976). The Tourist. New York: Schocken Books.

Madill, A., Jordan, A., \& Shirley, C. (2000). Objectivity and reliability in qualitative analysis: Realist, contextualist and radical constructionist epistemologies. British journal of psychology, 91(1), $1-20$.

Maddrell, A., \& della Dora, V. (2013). Crossing surfaces in search of the holy: landscape and liminality in contemporary Christian pilgrimage. Environment and Planning A, 45(5), 1105-1126. 
Megoran, N. (2013). Radical politics and the apocalypse: Activist readings of revelation. Area, 45, $141-147$

MGTO (2017). Macao Tourism Industry Development Master Plan. Macao Government Tourism Office (MGTO). Website: https://masterplan.macaotourism.gov.mo/home-en/index.html

Moore, A. (1980). Walt Disney World: Bounded Ritual Space and the Playful Pilgrimage Center. Anthropological Quarterly, 53(4), 207-218.

Moore, H.L. (2004). Global Anxieties: Concept-metaphors and Pre-theoretical Commitments in Anthropology. Anthropological Theory, 4(1), 71-88.

Morinis, E. A. (Ed) (1992). Sacred Journeys: The Anthropology of Pilgrimage. Westport. Greenwood Press.

Needham, J. (1995).Science et civilisation en Chine. Une introduction. Arles: Picquier.

Naquin, S., \& Yu, Chun-fang (1992). Pilgrims and Sacred Sites in China. University of California Press.

Olsen, D. H. (2016). Ritual Journeys in North America: Opening Religious and Ritual Landscapes and Spaces. International Journal of Religious Tourism and Pilgrimage, 4(1), Article 4. Available at: http://arrow.dit.ie/ijrtp/vol4/iss1/4

Papineau, E. (2005). Pathological Gambling in Montreal's Chinese Community: An anthropological perspective. Journal of Gambling Studies, 21(2), 157-178.

Pfaffenberger, B. (1983). Serious Pilgrims and Frivolous Tourists: The Chimera of Tourism in the Pilgrimages of Sri Lanka. Annals of Tourism Research, 10(1), 57-74.

Plate, S. B. (2009). The Varieties of Contemporary Pilgrimage. Cross Currents, 59(3), 260-267.

Pons, P. (2002). Macao. Hong Kong: Hong Kong University Press.

Presson, P. K. \& Besassi, V. A. (1996). Illusion of control: A meta-analytic review. Journal of Social Behavior and Personality, 11, 493-510.

Raj, S. J., \& Dempsey, C. G. (2010). Introduction: Ritual Levity in South Asian Traditions'. In. S. J. Raj \& C. G. Dempsey (Eds.), Sacred Play: Ritual Levity and Humor in South Asian Religions (pp. 1-20). Albany: State University of New York Press.

Raj, R., Griffith, K. (2015). Religious tourism and pilgrimage management: an international perspective. Wallingford, Oxfordshire: CABI Publishing.

Ron, A. S. (2009). Towards a Typological Model of Contemporary Christian Travel. Journal of Heritage Tourism, 4(4). 287-297.

Sacramento, O. (2011). Liminal spaces: reflections on the proxemia of cross-border demand for prostitution, Space and Culture, 14(4), 367-383.

Sangren, P. S. (2012). Fate, Agency, and the Economy of Desire in Chinese Ritual and Society. Social Analysis, 56(2), 117-135.

Santos, X. M. (2002). Pilgrimage and tourism at Santiago de Compostela. Tourism Recreation Research, 27(2), 41-50

Scriven, R. (2014). Geographies of pilgrimage: meaningful movements and embodied mobilities. Geography Compass, 8(4), 249-261.

Schüll, N. D. (2012). Addiction by Design: Machine Gambling in Las Vegas. Princeton: Princeton University Press.

Schumacher, E. F. (1973). Small is beautiful. New York: Harper \& Row.

Singh, R. P.B. (2009). Sacred Space and Faithscape; in, his: Geographical Thoughts in India: Snapshots and Vision for the 21st Century (pp. 227-265). Cambridge Scholars Publishing, Newcastle upon Tyne. U.K.

Sipiora, P., \& Baumlin, J. S. (Eds.), (2002). Rhetoric and Kairos: Essays in History, Theory, and Praxis. Albany, NY: State University of New York Press.

Shalin, D. N. (2016). Erving Goffman, Fateful Action, and the Las Vegas Gambling Scene. UNLV Gaming Research \& Review Journal, 20(1).

Smith, V. L. (1992). Introduction: The Quest in Guest. Annals of Tourism Research, 19(1), 1-17.

Søndergaard, D. M. (2002). Poststructuralist approaches to empirical analysis. International Journal of Qualitative Studies in Education, 15(2), 187-204.

St Pierre, E., \& Jackson, A. (2014). Qualitative data analysis after coding. Qualitative Inquiry, 20(6), 715-719. 
Steinmüller, H. (2011). The moving boundaries of social heat: gambling in rural China. Journal of the royal anthropological institute, 17(2), 263-280.

Taguchi, H. L. (2012). A diffractive and Deleuzian approach to analysing interview data. Feminist Theory, 13(3), 265-281.

Tang, C. S-K., \& Wu, A. M. S. (2010). Direct and Indirect Influences of Fate Control Belief, Gambling Expectancy Bias, and Self-Efficacy on Problem Gambling and Negative Mood Among Chinese College Students: A Multiple Mediation Analysis. Journal of Gambling Studies, 26(4), 533-543.

Tidball, D. (2004). The pilgrim and the tourist: Zygmunt Bauman and postmodern identity In. C. Bartholomew \& F. Hughes (Eds.), Explorations in a Christian theology of pilgrimage (pp. 184-99). Aldershot: Ashgate.

Timothy, D. J. \& Olsen, D. H. (2006). Tourism, religion \& spiritual journeys. New York, NY: Routledge.

Tsang, E. W. K. (2004). Toward a scientific inquiry into superstitious business decision-making. Organization Studies, 25, 923-946.

Tse, J. (2014). Grounded theologies: 'Religion' and the 'secular' in human geography. Progress in Human Geography, 38, 201-220

Turner, E. (2012). Communitas: The anthropology of collective joy, New York, NY: Palgrave Macmillan.

Turner, V. (1967). The Forest of Symbols, Ithaca: Cornell University Press.

Turner, V. (1968). The Drums of Affliction: A Study of Religious Process among the Ndembu of Zambia. Oxford: Clarendon Press.

Turner, V. (1969). The Ritual Process: Structure and Anti-Structure, Chicago: Aldine.

Turner, V. (1974a). Dramas, Fields and Metaphors: Symbolic Action in Human Society. Ithaca, N.Y: Cornell University Press (original essay published 1972).

Turner, V. (1974b). Liminal to Liminoid, in Play, Flow, and Ritual. Rice University Studies: The Anthropological Study of Human Play, 60(3), 53-92.

Turner, V. (1979). Frame, Flow and Reflection: Ritual and Drama as Public Liminality, Japanese Journal of Religious Studies, 6(4), 465-499

Turner, V. (1980). Social Dramas and Stories about Them. Critical Inquiry, 7(1), 141-168.

Turner, V. (1982). From Ritual to Theatre: The Human Seriousness of Play, New York: Performing Arts Journal Publications.

Turner, V., \& Turner, E. (1978). Image and Pilgrimage in Christian Culture: Anthropological Perspectives, New York: Columbia University Press.

Turner, V. (1992). Foreword. In. E. A. Morinis (Ed.), Sacred Journeys: The Anthropology of Pilgrimage (pp. vii-viii).Westport. Greenwood Press:

Van Gennep, A. (1960). The Rites of Passage, Translated by M. B. Vizedom \& G. L. Caffee. London: Routledge \& Keegan Paul.

Walter, E. V. (1988). Placeways. A Theory of the Human Environment. The University of North Carolina Press, Chapel Hill.

Wheeler, B. (1998). Pilgrimage and the Desire for Meaning. Cary M. Maguire Center for Ethics and Public Responsibility, Southern Methodist University.

Williams, R. (1980). Advertising: the magic system (1960), reprinted in Problems in Materialism and Culture (pp. 184-95). London: Verso,

Yang, M. M-h. (2011). Postcoloniality and Religiosity in Modern China: The Disenchantments of Sovereignty, Theory, Culture \& Society, 28(2), 3-45.

Zeng, Z. L., Prentice, C., \& King, B. E. (2012). To gamble or not? Perceptions of Macau among mainland Chinese and Hong Kong visitors, International Journal of Tourism Research, 16(2), 105-112.

Zhang, J. J. (2017). Paying homage to the 'Heavenly Mother': Cultural-geopolitics of the Mazu pilgrimage and its implications on rapprochement between China and Taiwan, Geoforum, 84, 32-41. 